\title{
Characteristics of three rhabdoviruses from snakehead fish Ophicephalus striatus
}

\author{
J. Kasornchandra ${ }^{1}$, H. M. Engelking ${ }^{2}$, C. N. Lannan ${ }^{3}$, J. S. Rohovec ${ }^{1}$, J. L. Fryer ${ }^{1, *}$ \\ ${ }^{1}$ Department of Microbiology, Oregon State University, Nash Hall 220, Corvallis, Oregon 97331-3804, USA \\ ${ }^{2}$ Oregon Department of Fish and Wildlife, Department of Microbiology, Oregon State University, Nash Hall 220. \\ Corvallis, Oregon 97331-3804, USA \\ ${ }^{3}$ Laboratory for Fish Disease Research, Department of Microbiology, Oregon State University, Mark O. Hatfield Marine \\ Science Center, Newport, Oregon 97365-5296, USA
}

\begin{abstract}
Protein profiles and serological characteristics of 3 rhabdoviruses from snakehead fish Ophicephalus striatus were determined and compared to 5 known fish rhabdoviruses and 1 mammalian rhabdovirus. The snakehead rhabdovirus (SHRV) exhibited a bacilliform morphology and a Lyssavirus-type protein profile. The ulcerative disease rhabdovirus isolates (UDRV-BP and UDRV-19) were indistinguishable and exhibited bullet-shaped morphology and a Vesiculovirus-type protein profile. At present, none of the 3 viruses is known to be the cause of disease in any species of fish. UDRV-BP and UDRV-19 were serologically identical but distinct from SHRV and from 5 other fish rhabdoviruses. SHRV was serologically unrelated to any of the fish rhabdoviruses examined.
\end{abstract}

\section{INTRODUCTION}

Since 1980 , a severe epizootic disease, often characterized by necrotic ulcerations, has occurred among both wild and cultured snakehead fish Ophicephalus striatus in southeast Asia, Malaysia, Thailand, Lao People's Democratic Republic and Burma (Boonyaratpalin 1989).

Various organisms (viruses, bacteria, fungi and higher parasites) were found to be associated with the diseased fish (Hedrick et al. 1986, Tonguthai 1986, Wattanavijarn et al. 1986, Boonyaratpalin 1989 . Frerichs et al. 1989). Six rhabdovirus isolations have been reported from snakehead fish with ulcerative disease; however, there is no known causal relationship. The snakehead rhabdovirus (SHRV) was isolated in Thailand by Wattanavijarn et al. (1986). Five isolations of ulcerative disease rhabdovirus (UDRV), 3 in Thailand and 2 in Burma, were made by Frerichs et al. (1989), and all were serologically homologous. Although the viruses have been individually described (Ahne et al. 1988), no detailed comparative studies

- Addressee for correspondence have been conducted. In this report, the morphology, structural proteins and serological characteristics of 3 isolates (SHRV, UDRV-BP and UDRV-19) are described and compared to each other and to other rhabdoviruses.

\section{MATERIALS AND METHODS}

Viruses and cell lines. SHRV was obtained in Thailand by Wattanavijarn et al. (1986) from snakehead with ulcerative disease; UDRV-BP and UDRV-19 were isolated from pooled organs of diseased fish in Thailand and Burma, respectively, by Frerichs et al. (1986). Five other fish rhabdoviruses, infectious hematopoietic necrosis virus (IHNV), viral hemorrhagic septicemia virus (VHSV), hirame rhabdovirus (HRV), spring viremia of carp virus (SVCV) and pike fry rhabdovirus (PFRV), were used for comparison. Vesicular stomatitis virus (VSV) New Jersey serotype, a mammalian rhabdovirus, was used for protein profile comparison.

All fish rhabdoviruses, except UDRV-BP and UDRV19, were propagated and titered in the Epithelioma 
papulosum cyprini (EPC) cell line (Fijan et al. 1983) cultured in Eagle's minimum essential medium with Earle's salts (MEM) supplemented with 5\% fetal bovine serum (FBS). VSV was propagated in baby hamster kidney cells (BHK-21) in MEM. UDRV-BP and UDRV-19 were grown in the snakehead fin cell line (SHF) (Kasormchandra et al, 1988) in Leibovitz's L-15 medium supplemented with $5 \% \mathrm{FBS}$. All culture media contained $100 \mathrm{U}$ penicillin and $100 \mathrm{mg}$ streptomycin $\mathrm{ml}^{-1}$. The viral titer $\left(\mathrm{TCID}_{50} \mathrm{ml}^{-1}\right)$ was determined by end-point dilution assay using 96-well plates with 6 wells per dilution and calculated by the method of Reed \& Muench (1938). Cells were incubated for $7 \mathrm{~d}$ at $27^{\circ} \mathrm{C}$.

Electron microscopy. Both SHRV and UDRV were inoculated on monolayer cell cultures at a multiplicity of infection (MOI) of 0.1 , and incubated at $27^{\circ} \mathrm{C}$ for $10 \mathrm{~h}$. The culture medium was then decanted and the cell sheet washed 3 times with Hanks' balanced salt solution (HBSS, pH 7.4) and fixed for $2 \mathrm{~h}$ with $2.5 \%$ glutaraldehyde in HBSS. The cell sheet was then washed 3 times with $0.2 \mathrm{M}$ cacodylate buffer ( $\mathrm{pH} 7.3$ ), harvested with a scraper, and centrifuged at $1000 \times g$ for $10 \mathrm{~min}$. The pellet was post-fixed with $1 \%$ osmium tetroxide in $0.2 \mathrm{M}$ sodium cacodylate buffer for $1 \mathrm{~h}$, washed, dehydrated, and embedded in MedcastAradite 502. The cells were sectioned and viewed with a Zeiss EM10/A at $60 \mathrm{kV}$.

Virus purification. All viruses were purified in the following manner. The cell monolayers were inoculated at an MOI of 0.001 and incubated at appropriate temperatures (Wolf 1988) until cytopathic effect (CPE) was complete. Culture fluid was harvested, clarified by centrifugation at $4000 \times g$ for $10 \mathrm{~min}$, and the virus concentrated by centrifugation at $80000 \times g$ for $90 \mathrm{~min}$. The viral pellet was resuspended in $0.01 \mathrm{M}$ tris$\mathrm{HCl}$ buffer, $\mathrm{pH} 7.5$, and purified on discontinuous and continuous sucrose gradients (Engelking \& Leong 1989). Purified virus was resuspended in $0.35 \mathrm{ml}$ tris$\mathrm{HCl}$ buffer and stored at $-70^{\circ} \mathrm{C}$

Analysis of viral structural proteins. Viral proteins denatured with SDS were separated by discontinuous polyacrylamide gel electrophoresis (SDSPAGE). Using a $4.75 \%$ stacking and $10 \%$ separating gel (Laemmli 1970), polypeptides were electrophoresed under a constant $200 \mathrm{~V}$ for $45 \mathrm{~min}$ and visualized using a silver nitrate stain.

Glycosylation of viral glycoproteins. The glycosylated proteins of purified SHRV, UDRV-BP and UDRV-19 were identified by enzyme-linked immunosorbant assay (ELISA) using a glycan detection kit (Boehringer Mannheim Biochemicals, Indianapolis, IN, USA). Transferrin was used as a positive control and the standard molecular weight protein markers served as a negative control.
Polyclonal antibody production. Polyclonal mouse antibody to SHRV, HRV, SVCV, PFRV, UDRV-BP and UDRV-19 was prepared as follows. Viral protein $(60 \mu \mathrm{g}$ $\mathrm{ml}^{-1}$ ) was mixed with an equal amount of Freund's complete adjuvant and the emulsion was injected intraperitoneally (IP) into three 8-wk-old female $\mathrm{BALB} / \mathrm{C}$ micc. Two booster injections containing $30 \mu \mathrm{g}$ of viral protein mixed with Freund's incomplete adjuvant (Sigma) were given IP at 1 mo intervals. Four days after the second booster, the mice were primed with an IP injection of $1.0 \mathrm{mg}$ viral protein. Four days later, $3.3 \times 10^{6}$ sarcoma $180 /$ TG cells in $0.3 \mathrm{ml}$ sterile saline $(0.15 \mathrm{M} \mathrm{NaCl})$ were injected IP. Ascitic fluid was collected after 10 to $15 \mathrm{~d}$, clarified by centrifugation at $1000 \times g$ for $5 \mathrm{~min}$, passed through a $0.45 \mu \mathrm{m}$ sterile membrane filter, and stored in $1.0 \mathrm{ml}$ aliquots at $-70^{\circ} \mathrm{C}$.

Cross-neutralization test. Cross-neutralization was performed by the alpha method of Rovozzo \& Burke (1973). Each 10 -fold virus dilution was reacted at $22^{\circ} \mathrm{C}$ for $1 \mathrm{~h}$ with an equal volume of titered polyclonal antibody diluted appropriately for neutralization of 100 $\mathrm{TCID}_{50}$ 's of homologous virus. The virus-antibody combination was assayed for infectivity by inoculating $0.2 \mathrm{ml}$ of each dilution into each of 3 wells of a microplate containing a confluent monolayer. IHNV, VHSV and HRV infected cultures were incubated at $14{ }^{\circ} \mathrm{C}$; SVCV and PFRV at $20^{\circ} \mathrm{C}$; and SHRV, UDRV-BP and UDRV-19 at $27^{\circ} \mathrm{C}$. Incubation was continued until obvious CPE had developed in the virus-control wells and the $\log _{10}$ neutralization indices (NI) were determined (Rovozzo \& Burke 1973).

\section{RESULTS}

\section{Electron microscopy}

SHRV had bacilliform morphology (Fig. 1a), with a range of 180 to $200 \mathrm{~nm}$ in length and 60 to $70 \mathrm{~nm}$ in width. In contrast, UDRV-BP and UDRV-19 particles exhibited a bullet-shape morphology (Fig. 1b, c) with size ranging from 110 to $130 \mathrm{~nm}$ in length and 50 to $65 \mathrm{~nm}$ in width. Numerous virus particles were found in the cytoplasm and budding through the cell membranes.

\section{Analysis of viral structural proteins}

The polypeptides of the 9 rhabdoviruses separated by SDS-PAGE gave 2 distinct patterns (Fig. 2). The first pattern, exhibited by IHNV, VHSV, HRV and SHRV, was similar to that of rabies virus (Lenoir \& de Kinkelin 1975, Coslett et al. 1980). The second pattern, exhibited by SVCV, PFRV, UDRV-BP and UDRV-19, more closely resembled that of VSV as seen in Lane 9 (McAllister \& Wagner 1975, Wagner 1975). 
The estimated molecular weights of the structural proteins of SHRV, IHNV, VHSV and HRV are shown in Table 1. Although the banding patterns were similar for these 4 viruses, differences in the migration of individual proteins were observed. These differences are reflected in the range of molecular weights determined for the G, N, M1 and $\mathrm{M} 2$ proteins.

The molecular weights of the viral proteins of SVCV, PFRV, UDRV-BP and UDRV-19 were estimated (Table 2). The proteins of the 2 UDRV isolates were equivalent in size. Though evident for UDRV-BP and UDRV-19, the non-structural (NS) proteins of SVCV, PFRV and VSV could not be identified (Fig. 2), but the $\mathrm{N}$ and $\mathrm{M}$ proteins of the UDRV isolates were intermediate in size between those of SVCV and PFRV, and the UDRV G protein was smaller than either of the other two. It was determined, by ELISA, that the $68 \mathrm{kDa}$ protein of SHRV and the $71 \mathrm{kDa}$ protein of UDRV-BP and UDRV-19 were glycosylated.

\section{Cross-neutralization tests}

The greatest neutralizing activity in the mouse ascitic fluid was obtained with SVCV with a titer of $1: 126$, and the lowest titer was from HRV at $1: 64$. The mouse ascitic fluid had a toxic effect on the cells, so the lowest dilution permitting detection of viral CPE was $1: 16$. The anti-IHNV and anti-VHSV rabbit antisera had neutralizing titers of $1: 100$ and $1: 256$, respectively. In the crossneutralization assay, 8 fish rhabdoviruses were compared (Table 3). SHRV, IHNV, VHSV, HRV, SVCV and PFRV were not significantly neutralized by antisera to any of the heterologous viruses. However, strong cross-neutralization occurred between the UDRV-BP and UDRV-19.

\section{DISCUSSION}

Six rhabdovirus isolations have been made from the diseased snakehead fish in Thailand and Burma. Characteristics of 3 rhabdovirus isolates, SHRV and UDRV-BP from Thailand and UDRV-19

Fig. 1. (a) Electron micrograph of an ultrathin section of EPC cells infected with the snakehead rhabdovirus (SHRV). Scale bar $=260 \mathrm{~nm}$. (b) Thin section of SHF cells infected with the ulcerative disease rhabdovirus (UDRV-BP). Scale bar $=143 \mathrm{~nm}$. (c) Thin section of SHF cells infected with the ulcerative disease rhabdovirus (UDRV-19). Scale bar $=97 \mathrm{~nm}$

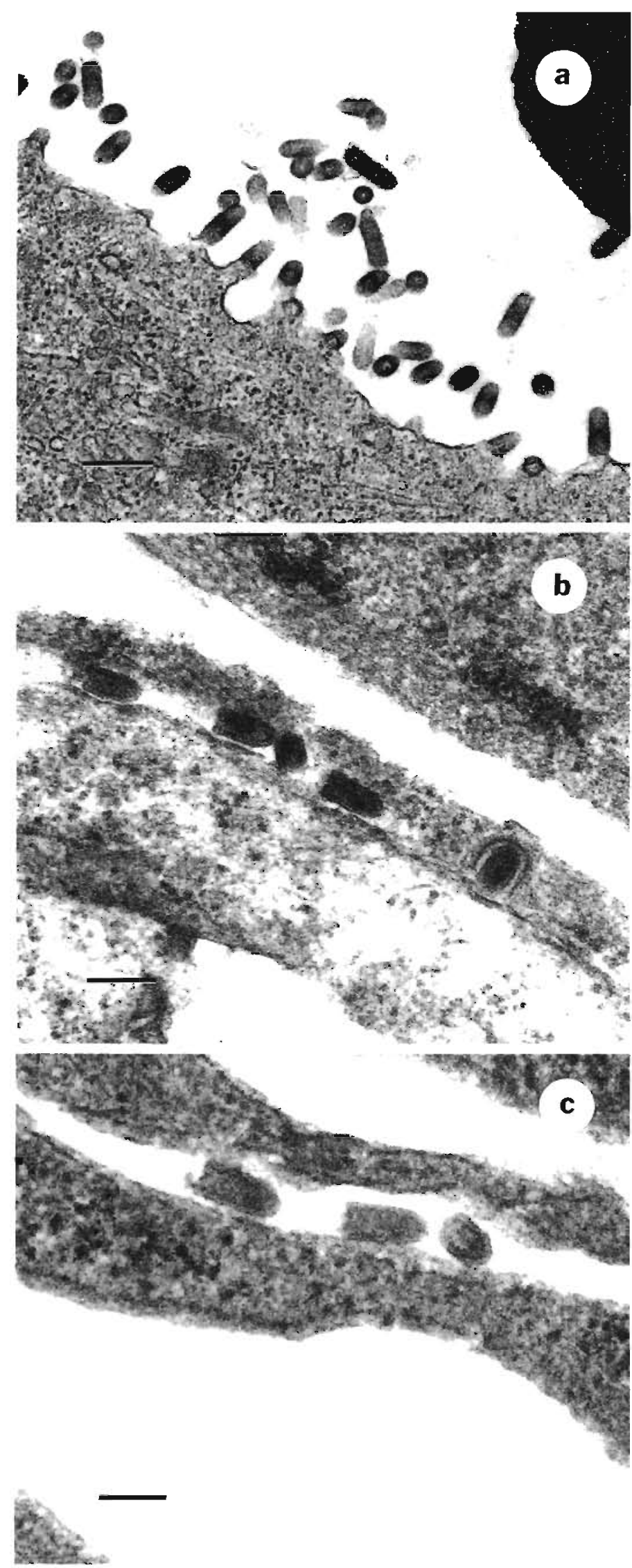




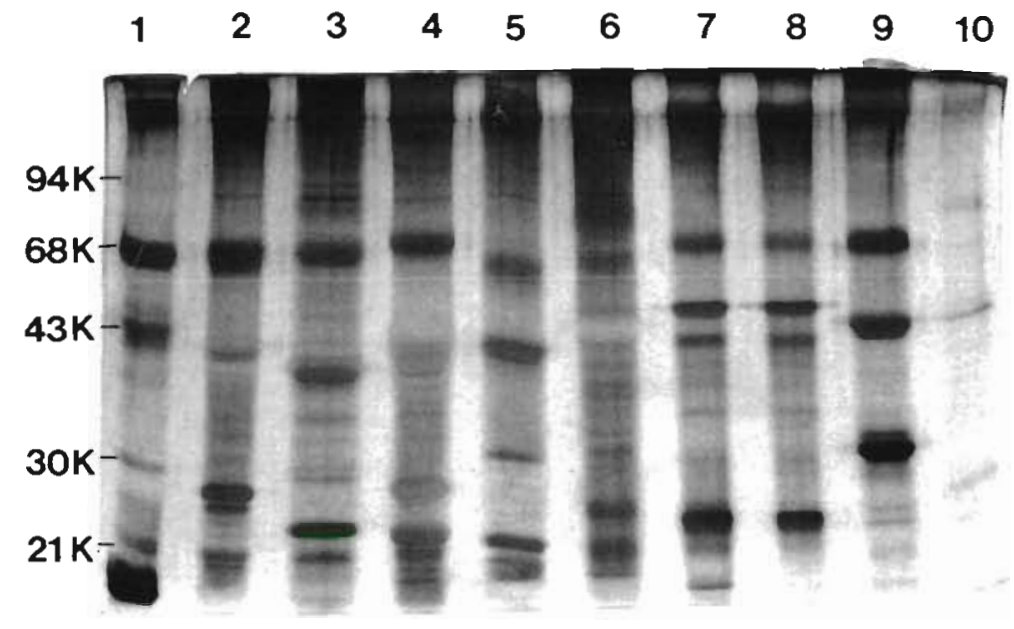

Fig. 2. A comparison of the viral polypeptides of 3 snakehead rhabdovirus isolates, 5 other fish rhabdoviruses and a mammalian virus, VSV, by polyacrylamide gel electrophoresis. The gel was stained with silver nitrate Lane 1: molecular weight markers phosphorylase B (94 kDa), bovine serum albumin (68 $\mathrm{kDa})$, ovalbumin $(43 \mathrm{kDa})$, carbonic anhydrase $(30 \mathrm{kDa})$, soybean trypsin inhibitor $(21 \mathrm{kDa})$ and lysozyme $(14 \mathrm{kDa})$. Lane 2: snakehead rhabdovirus (SHRV). The estimated molecular weight of the 5 virion protein components of SHRV were $>150,68,42,26.5$ and $20 \mathrm{kDa}$ These proteins likely correspond to those previously characterized as the L, G, N, M1 and M2 structural proteins of IHNV, VHSV and HRV (McAllister \& Wagner 1975, Hsu et al. 1985, Kimura et al. 1989). Lane 3: infectious hematopoietic necrosis virus (IHNV). Lane 4: viral hemorrhagic septicemia virus (VHSV). Lane 5: hirame rhabdovirus (HRV). Lane 6: spring virema of carp virus (SVCV). Lane 7: ulcerative disease rhabdovirus (UDRV-BP). Lane 8: ulcerative disease rhabdovirus (UDRV-19). These may correspond to the $\mathrm{L}, \mathrm{G}, \mathrm{N}$ and $\mathrm{M}$ proteins of SVCV and PFRV (Lenoir 1973, de Kinkelin et al. 1974). A minor protein of both UDRV-BP and UDRV-19 with a molecular weight of $48 \mathrm{kDa}$ was also observed in this gel. Lane 9: vesicular stomatitis virus (VSV). Lane 10: pike fry rhabdovirus (PFRV)

from Burma, were described and compared. Electron micrographs of these viruses in thin section showed that the particle size of UDRV-BP and UDRV-19 was the same, and both had a typical bullet shape similar to that of other fish rhabdoviruses (Hill et al. 1975, 1980, Kimura et al. 1986). Our observations of the size and shape of the UDRV isolates were similar to those reported by Frerichs et al. (1986) and were different from those of the SHRV. In contrast to the UDRV isolates,
SHRV exhibited bacilliform morphology that is commonly found in plant rhabdoviruses (Hetrick 1989), although Malsberger \& Lautenslager (1980) reported a rhabdovirus (Rio Grande perch rhabdovirus) with bacilliform morphology that was isolated from a fish of the family Cichlidae.

The 8 fish rhabdoviruses tested (IHNV, SHRV, VHSV, HRV, SVCV, UDRV-BP, UDRV-19 and PFRV) can be separated into 2 groups based on their SDS-PAGE protein profiles. The first group (IHNV, SHRV, VHSV, HRV) was composed of virions whose structural protein profile closely resembled that of rabies virus, the prototype virus of the Lyssavirus genus of the family Rhabdoviridae. These proteins are classified as $L$ for the polymerase, $G$ for the surface glycoprotein, $\mathrm{N}$ for the nucleocapsid and M1 and M2 for the envelope matrix proteins (Wagner et al. 1972, Lenoir \& de Kinkelin 1975, McAllister \& Wagner 1975). The second group of viruses contained SVCV, UDRV-BP, UDRV-19 and PFRV. These viruses are composed of 4 major structural proteins ( $L, G, N$ and $M$ ). In addition, both UDRV-BP and UDRV-19 showed a minor structural protein with a molecular weight of $48 \mathrm{kDa}$ similar to the structural protein (NS) of VSV. A minor protein of similar molecular weight has been reported for SVCV and PFRV but was not detected by us (Wolf 1988). Based on structural protein profile and molecular weights, UDRV-BP and UDRV-19 seem identical. The protein banding patterns of these viruses resemble that of VSV, the prototype virus of the genus Vesiculovirus (Wagner 1975).

By ELISA, the presence of a single glycosylated structural protein of SHRV with an apparent molecular weight of $68 \mathrm{kDa}$ was detected. Similarly, UDRV has a single structural glycosylated protein of the somewhat greater apparent molecular weight of $71 \mathrm{kDa}$ (Fig. 2). The rhabdoviral glycoprotein

Table 1 Estimated molecular weights $\left(\times 10^{3} \mathrm{Da}\right)$ of virion structural proteins of snakehead rhabdovirus (SHRV), infectious hematopoietic necrosis virus (IHNV), viral hemorrhagic septicemia (VHSV) and hirame rhabdovirus (HRV)

\begin{tabular}{|c|c|c|c|c|c|}
\hline \multicolumn{6}{|c|}{ Lyssavirus-like group } \\
\hline \multirow[t]{2}{*}{ Virus } & \multirow{2}{*}{$\begin{array}{c}\text { Polymerase } \\
\text { L }\end{array}$} & \multirow{2}{*}{$\begin{array}{c}\text { Glycoprotein } \\
G\end{array}$} & \multirow{2}{*}{$\underset{N}{\text { Nucleoprotein }}$} & \multicolumn{2}{|c|}{ Matrix proteins } \\
\hline & & & & M1 & $\mathrm{M} 2$ \\
\hline SHRV & $>150$ & 68 & 42 & 26.5 & 20 \\
\hline IHNV & $>150$ & 67 & 40.5 & 28 & 22.5 \\
\hline VHSV & $>150$ & 72 & 42 & 26.5 & 22 \\
\hline HRV & $>150$ & 60 & 42.5 & 30 & 22 \\
\hline
\end{tabular}


Table 2. Estimated molecular weights $\left(\times 10^{3} \mathrm{Da}\right)$ of virion structural proteins of spring viremia of carp virus (SVCV), ulcerative disease rhabdoviruses (UDRV-BP and UDRV-19) and pike fry rhabdovirus (PFRV)

\begin{tabular}{|c|c|c|c|c|}
\hline \multicolumn{5}{|c|}{ Vesiculovirus-like group } \\
\hline Virus & $\begin{array}{c}\text { Polymerase } \\
\text { L }\end{array}$ & $\begin{array}{c}\text { Glycoprotein } \\
G\end{array}$ & $\underset{N}{\text { Nucleoprotein }}$ & $\begin{array}{c}\text { Matrix protein } \\
M\end{array}$ \\
\hline SVCV & $>150$ & 85 & 45 & 23 \\
\hline UDRV-BP & $>150$ & 71 & 53 & 22 \\
\hline UDRV-19 & $>150$ & 71 & 53 & 22 \\
\hline PFRV & $>150$ & 80 & 43 & 24 \\
\hline
\end{tabular}

Table 3. Cross-neutralization tests for 8 fish rhabdoviruses

\begin{tabular}{|c|c|c|c|c|c|c|c|c|}
\hline \multirow[t]{3}{*}{ Virus } & \multicolumn{8}{|c|}{ Polyclonal antisera } \\
\hline & SHRV & IHNV & VHSV & HRV & SVCV & UDRV-BP & UDRV-19 & PFRV \\
\hline & $1: 112^{\mathrm{a}}$ & 1100 & $1: 256$ & $1: 64$ & $1: 126$ & 1.64 & $1: 64$ & 1.96 \\
\hline Snakehead rhabdovirus (SHRV) & $2.0^{b}$ & 0 & 0 & 0 & 0 & 0 & 0 & 0 \\
\hline Infectious hematopoietic necrosis virus (IHNV) & 0 & 1.8 & 0 & 0 & 0 & 0 & 0 & 0 \\
\hline Viral hemorrhagic septicemia virus (VHSV) & 0 & 0 & 1.8 & 0 & 0 & 0 & 0 & 0 \\
\hline Hirame rhabdovirus (HRV) & 0 & 0 & 0 & 1.8 & 0 & 0 & 0 & 0 \\
\hline Spring viremia of carp virus (SVCV) & 0 & 0 & 0 & 0 & 2.0 & 0 & 0 & 0 \\
\hline Ulcerative disease rhabdovirus (UDRV-BP) & 0 & 0 & 0 & 0 & 0 & 2.0 & 1.9 & 0 \\
\hline Ulcerative disease rhabdovirus (UDRV-19) & 0 & 0 & 0 & 0 & 0 & 1.9 & 2.0 & 0 \\
\hline Pike fry rhabdovirus (PFRV) & 0 & 0 & 0 & 0 & 0 & 0 & 0 & 1.8 \\
\hline
\end{tabular}

occurs on the viral envelope and can elicit neutralizing antibody (Kelley et al. 1972, Cox et al. 1977, Engelking \& Leong 1989). By western blot, the polyclonal antibody against SHRV reacted with the $G$ protein of all the fish rhabdoviruses examined. A similar result was obtained with polyclonal antiserum to the purified $G$ protein of IHNV when reacted with SHRV, IHNV and VHSV (data not shown). This cross-reaction may indicate a conserved, non-neutralizing, linear epitope in the $G$ protein of these fish rhabdoviruses. This region may possibly be important in anchoring the $G$ protein to the capsid.

Serological comparison of SHRV, UDRV-BP, UDRV19 and 5 other fish rhabdoviruses showed that SHRV is unique and that UDRV-BP and UDRV-19 are serologically identical but distinct from other fish rhabdoviruses examined. Although the SHRV and UDRV were originally obtained from the same host species, they can be distinguished by their morphology, serological characteristics and structural proteins. Both rhabdoviruses from snakehead fish should be regarded as distinct viruses. The relation of these viruses to the ulcerative disease of snakehead fish is unknown.
Acknowledgements. We thank W. Wattanavijarn, Chulalongkorn University, Thailand, for providing the SHRV; $T$ Kiumura, Hokkaido University, Japan, for providing the viruses HRV and PFRV; and G. N. Frerichs, University of Stirling, UK, for providing the UDRV-BP and UDRV-19. We also thank J. R. Winton, National Fisheries Research Center, Seattle, Washington, for providing the VHSV antiserum and J. L. Bartholomew for assistance in immunizing mice. This publication is the result, in part, of research sponsored by Oregon Sea Grant with funds from the National Oceanic and Atmospheric Administration, Office of Sea Grant, Dept. of Commerce, under grant No. NA 89AA-D-SG 108 (project No. R-FSD-14) and USAID under project identification No. 7-276. This is Oregon Agricultural Experiment Station Technical Paper No. 9654.

\section{LITERATURE CITED}

Ahne, W., Jorgensen, P. E. V., Olesen, N. J., Wattanavijarn, W. (1988). Serological examination of a rhabdovirus isolated from snakehead fish (Ophicephalus striatus) in Thailand with ulcerative syndrome. J. appl. Ichthyol. 4: 194-196

Boonyaratpalin, S. (1989). Bacterial pathogens involved in the epizootic ulcerative syndrome of fish in southeast Asia. J. aquat. Anim. Health 1: 272-276

Coslette, G. D., Holloway, B. P., Obijeski, J. F. (1980). The structural proteins of rabies virus and evidence for their synthesis from separate monocistronic RNA species. J. gen. Virol. 49: 161-180 
Cox, J H., Dietzschold, B. Schneider, L. G. (1977). Rabies virus glycoprotein. II. Biological and serological characterization. Infect. Immun. 16: 754-759

Engelking, H. M., Leong, J. C. (1989). Glycoprotein from infectious hematopoietic necrosis virus (IHNV) induces protective immunity against five IHNV types. J. aquat. Anim. Health 1: 291-300

de Kinkelin, P., Le Berre, M., Lenoir, G. (1974). Rhabdovirus des poissons. I. Propriétés in tro du virus de la maladie rongé de l'alevin de brochet. Annls Inst. Pasteur' Microbiol. 125A: 93-111

Fijan, N., Sulimanovic, D., Bearyotti, M., Muzinic, D. Zwillenberg, L. O., Chilmonczyk, S., Vautherot, J. F., de Kinkelin, P. (1983). Some properties of the Epithelioma papulosum cyprini (EPC) cell line from carp Cyprinus carpio. Annls Inst. Pasteur/Virol. 134E: 207-220

Frerichs, G. N., Millar, S. D., Roberts, R. J. (1986). Ulcerative rhabdovirus in fish in Southeast Asia. Nature, Lond. 322: 216

Frerichs, G. N., Hill, B. J., Way, K. (1989). Ulcerative disease rhabdovirus: cell-line susceptibility and serological comparison with other fish rhabdoviruses. J. Fish Dis. 12: $51-56$

Hedrick, R. P., Eaton, W. D., Fryer, J. L., Groberg, W. G. Jr, Boonyaratpalin, S. (1986). Characteristics of a birnavirus isolated from cultured sand goby Oxyeleotris marmoratus. Dis. aquat. Org. 1. 219-225

Hetrick, F. M. (1989). Fish viruses. In: Austin, B., Austin, A. D. (eds.) Methods for the microbiological examination of fish and shellfish. Ellis Horwood Limited, West Sussex, p. $216-239$

Hill, B. J., Underwood, B. O., Smale, C. J., Brown, F. (1975) Physico-chemical and serological characterizations of five rhabdoviruses infecting fish. J. gen. Virol 27:369-378

Hill, B. J., Williams, R. F., Smale, C. J., Underwood, B. O., Brown, F. (1980). Physico-chemical and serological characterization of two rhabdoviruses isolated from eels. Intervirology 14: 208-212

Hsu, Y. Engelking, H. M., Leong, J. C. (1985). Analysis of the quantity and synthesis of the virion proteins of the infectious hematopoietic necrosis virus. Fish Pathol. 20: $331-338$

Kasornchandra, J., Boonyaratpalin, S., Saduadee, J. (1988). Fish cell line initiated from snakehead fish (Ophicephalus striatus, Bloch) and its characters. National Inland Fisheries

Responsible Subject Editor: W. Ahne, Munich, Germany
Institute, Department of Fisheries, Bangkok, Technical Paper No. 90

Kelley, J. M., Emerson, S. U., Wagner, R. R. (1972). The glycoprotein of vesicular stomatitis virus is in the antigen that gives rise to and reacts with neutralizing antibody. J. Virol 10: $1231-1235$

Kimura, T., Yoshimizu, M., Gorie, S. (1986). A new rhabdovirus isolated in Japan from cultured hirame (Japanese flounder) Paralichthys olivaceus and ayu Plecoglossus altivelis. Dis. aquat. Org. 1: 209-217

Laemmli, U. K. (1970). Cleavage of structural proteins during the assembly of the head of bacteriophage T4. Nature, Lond. 227: 680-685

Lenoir, G. (1973). Structural proteins of spring viremia virus of carp. Biochem. biophys. Res. Commun. 51: 895-898

Lenoir, G., de Kinkelin, P. (1975). Fish rhabdoviruses: comparative study of protein structure. J. Virol. 16: 259-262

Malsberger, R. G., Lautenslager, G. (1980). Fish viruses: rhabdovirus isolated from a species of the family Cichlidae. Fish Health News 9: i-ii

McAllister, P. E., Wagner, R. R. (1975). Structural proteins of two salmonid rhabdoviruses. J. Virol. 15: 733-738

Reed, L. J., Muench, H. (1938). A simple method of estimating fifty percent end points. Amer. J. Hyg. 27: 493-497

Rovozzo, G. C., Burke, C. N. (1973). A manual of basic virological techniques. Prentice-Hall, New Jersey

Tonguthai, K. (1986). Parasitological findings. In: Roberts et al. (eds.) Field and laboratory investigations into ulcerative fish diseases in the Asia-Pacific region. Technical Report of FAO Project TCP/RAS/4508, Bangkok, p. $35-42$

Wagner, R. R. (1975). Reproduction of rhabdoviruses. In: Fraenkel-Conrat, H., Wagner, D. D. (eds.) Comprehensive virology, Vol. 4. Plenum Publishing Corp., New York, p. $1-93$

Wagner, R. R., Prevec, L., Brown, F., Summers, D. F, Sokol, F., MacLeod, R. (1972). Classification of rhabdovirus proteins: a proposal. J Virol. 10: 1228-1230

Wattanavijarn, W., Tangtronpiros, J., Wattanadorn, K. (1986). Viruses of ulcerative diseased fish in Thailand, Burma, and Laos. In: First International Conference on the Impact of Viral Diseases on the Development of Asian Countries. WHO. (Abstract) p. 121

Wolf, K. (1988). Fish viruses and fish viral diseases. Cornell Press, Ithaca, New York

Manuscript first received: October 10, 1991 Revised version accepted: May 5, 1992 